\title{
Struktur Histologi Hepar Puyuh Jepang (Coturnix coturnix japonica) yang Diberi Pakan Organik
}

\section{The Liver Histology Structure of Japanese Quails (Coturnix coturnix japonica) Marked Organic Feed}

\author{
Ika Oktavia Nurmila ${ }^{1 *}$, Tyas Rini Saraswati ${ }^{2}$, Sri Isdadiyanto ${ }^{2}$ \\ ${ }^{1}$ Mahasiswa Program Studi Biologi, Departemen Biologi, Fakultas Sains dan Matematika, \\ Universitas Diponegoro \\ ${ }^{2}$ Departemen Biologi, Fakultas Sains dan Matematika, Universitas Diponegoro \\ Jl. Prof. Soedarto, SH. Tembalang-Semarang 50275 \\ *Email : ikaoktaviamila18@gmail.com
}

Diterima 8 November 2018 / Disetujui 25 Februari 2019

\begin{abstract}
ABSTRAK
Penelitian ini bertujuan mengkaji pengaruh pemberian pakan organik terhadap diameter hepatosit dan struktur histologi hepar puyuh jepang (Coturnix coturnix japonica). Penelitian ini menggunakan 60 ekor puyuh jepang yang terdiri atas 4 perlakuan, masing-masing perlakuan terdiri atas 3 ekor puyuh dan dilakukan 5 kali ulangan. Perlakuan dalam penelitian terdiri atas 4 kelompok yaitu P0 merupakan puyuh yang diberi pakan komersial, P1 merupakan puyuh yang diberi pakan organik standar, P2 merupakan puyuh yang diberi pakan organik dengan kandungan daun singkong, kunyit, dan ikan kembung, dan P3 merupakan puyuh yang diberi pakan organik dengan kandungan daun singkong, kunyit, dan rumput laut. Perlakuan diberikan selama 4 bulan. Penelitian menggunakan Rancangan Acak Lengkap (RAL). Parameter yang diukur dalam penelitian adalah diameter hepatosit, diameter lobulus hepar, bobot hepar, dan bobot badan puyuh jepang serta deskripsi struktur histologi hepar. Data dianalisis dengan Analysis of Varian (ANOVA), bila terdapat perbedaan dilanjutkan dengan Uji Duncan dengan taraf kepercayaan 95\%. Hasil analisis data terdapat perbedaan nyata pada diameter hepatosit, diameter lobulus hepar, dan bobot hepar, namun tidak terdapat perbedaan nyata terhadap bobot badan puyuh jepang yang diberi pakan organik. Disimpulkan bahwa pemberian pakan organik mampu mengoptimalkan fungsi hepar puyuh.
\end{abstract}

Kata kunci: pakan organik, puyuh jepang, hepatosit, kunyit

\begin{abstract}
This study aimed to assess the effect of organic feeding on hepatocytes diameter and the liver histological structure of Japanese quail (Coturnix coturnix japonica). This study used 60 Japanese quails which consisted of 4 treatments, each treatment consisted of 3 quail and 5 replications. Observations in this study consisted of 4 groups of P0 was a commercial-feed quail, P1 was a quail feed standard organic, P2 was ann organic feed quail contained cassava leaves, turmeric, and mackerel, and P3 was an organic feed quail contained cassava leaves, turmeric, and seaweed. Treatment was given for 4 months. Completely Randomized Design (CRD) was used as method fot this study. The parameters were hepatocyte diameter, hepatic lobular diameter, hepatic weight and body weight of Japanese quail and description of hepatic histology structure. Data were analyzed with Analysis of Variant (ANOVA), if it had a significant difference, then Duncan Test was done with 95\% significant level. The result of data analysis showed significant difference in hepatocyte diameter, hepatic lobular diameter and hepatic weight, but there was no significant difference to body weight of Japanese quail given organic feed. Based on the result, showed the ability to optimizing quails hepatic function.
\end{abstract}

Keywords: organic feed, japanese quail, hepatocyte, turmeric 


\section{PENDAHULUAN}

Perkembangan populasi puyuh di Indonesia dari tahun ke tahun mengalami peningkatan. Perkembangan populasi puyuh dari tahun 20142018, yaitu 12.692.213-14.877.105 ekor. Hal ini juga menunjukkan peningkatan produksi telur puyuh di Indonesia dari tahun 2014-2018 dengan total produksi yaitu 20.709-24.555 ton (Direktorat Jenderal Peternakan dan Kesehatan Hewan, 2018). Produksi telur puyuh yang meningkat dari tahun ke tahun masih belum mencukupi kebutuhan protein hewani telur di Indonesia, dimana produksi telur puyuh saat ini hanya 3,0-3,5 juta butir per pekan, sedangkan kebutuhan protein telur puyuh yang harus dipenuhi yaitu 7,5-8,0 juta butir per pekan (Zahra dkk., 2012).

Standar konsumsi protein hewani yang di tetapkan oleh Food and Agriculture Organization (FAO) minimal $6 \mathrm{~g} / \mathrm{kapita} / \mathrm{hari}$, sedangkan konsumsi protein hewani di Indonesia saat ini sebesar 4,19 g/kapita/hari (Setioko dkk., 2014). Kebutuhan protein telur di Indonesia yang masih rendah perlu ditingkatkan dengan meningkatkan produktivitas dan kualitas telur puyuh. Produksi telur puyuh dapat ditingkatkan dengan penggunaan pakan organik sebagai alternatif untuk mengoptimalkan proses metabolisme dan produktivitas, sehingga produktivitas yang semakin meningkat akan mempengaruhi aktifitas sel hepar.

Penggunaan pakan organik sebagai pakan memiliki manfaat lebih dibandingkan pakan komersial. Pakan komersial merupakan campuran beberapa bahan yang dimanfaatkan untuk memenuhi kebutuhan energi ternak, namun nutrisi yang terkandung masih kurang optimal. Kekurangan penggunaan pakan komersial, yaitu kandungan serat kasar dalam pakan masih tinggi dibandingkan pakan organik (Sondakh dkk., 2015). Penggunaan pakan yang mengandung serat kasar tinggi dapat menurunkan tingkat metabolisme dalam hepar (Bahri dan Rusdi, 2008). Efektifitas fungsi hepar yang menurun menyebabkan kinerja hepar kurang optimal. Penurunan fungsi hepar ditandai dengan penurunan bobot hepar, penurunan diameter hepatosit, peningkatan SGPT dan SGOT. (Saraswati, 2015).

Pemberian pakan organik pada puyuh berperan dalam meningkatkan efektivitas fungsi sel hepar pada puyuh dalam melakukan sintesis vitelogenin, hal ini ditandai dengan meningkatnya ukuran hepatosit karena adanya akumulasi vitelogenin di dalam hepatosit (Saraswati, 2015). Tujuan dari penelitian ini, yaitu untuk mengetahui pengaruh pemberian pakan organik terhadap ukuran diameter hepatosit dan struktur histologi hepar puyuh Jepang (Coturnix coturnix japonica), sehingga pemberian pakan organik diharapkan mampu mengoptimalkan kerja sel hepar dalam proses metabolisme, sehingga mampu meningkatkan kualitas dan produktivitas telur puyuh.

\section{METODE PENELITIAN}

Bahan yang digunakan dalam penelitian ini adalah puyuh Jepang (Coturnix coturnix japonica) betina berumur 10 hari. Bahan uji berupa pakan organik, yaitu pakan komersial (P0) sebagai pakan kontrol, pakan organik standar (P1), pakan organik yang mengandung daun singkong, kunyit dan ikan kembung (P2), dan pakan organik yang mengandung daun singkong, kunyit, dan rumput laut. Bahan uji lain seperti garam fisiologis, aquades dan larutan BNF 10\%. Proses Aklimasi hewan uji berupa puyuh Jepang betina berumur 10 hari dilakukan dengan cara diadaptasikan pada lingkungan kandang pada suhu ruang selama 1 minggu sebelum melakukan perlakuan. Puyuh dimasukkan ke dalam kandang secara kolektif dengan kepadatan 1 kandang berisi 8 ekor.

Rancangan percobaan yang digunakan adalah Rancangan Acak Lengkap (RAL). Hewan uji yang digunakan pada penelitian ini adalah puyuh sebanyak 60 ekor yang diambil secara acak, dengan rincian 4 perlakuan, masing-masing terdiri atas 3 ekor puyuh dengan 5 kali ulangan. Data berupa bobot badan puyuh didapatkan dari hasil penimbangan yang dilakukan sebelum pembedahan. Penimbangan dilakukan dengan meletakkan puyuh jepang ke dalam wadah tertutup kemudian ditimbang dengan timbangan $\mathrm{T}$-Scale 
dengan ketelitian 0,01 kg. Data berupa bobot hepar puyuh didapatkan dari hasil pembedahan di akhir penelitian. Organ hepar diambil dan ditimbang menggunakan timbangan digital dengan ketelitian $0,01 \mathrm{~g}$, selanjutnya disiram dengan garam fisiologis dan difiksasi dalam botol flakon berisi larutan Buffered Neutral Formalin (BNF) 10\%.

Data berupa diameter hepatosit dan diameter lobulus hepar didapatkan dari hasil pengamatan preparat histologi hepar puyuh Jepang menggunakan fotomikrograf Olympus perbesaran 40x10. Setiap preparat histologi hepar puyuh diamati dan dipilih 5 lobulus hepar dan 5 hepatosit, kemudian diukur diameternya. Pengukuran diameter hepatosit dilakukan dengan cara membagi penampang menjadi tegak lurus berdasarkan garis horizontal (x) dan garis vertikal (y) apabila penampang hepatosit berbentuk bulat. Penampang hepatosit yang tidak simetris maka pengukuran diameter hepatosit dilakukan dengan cara membagi penampang hepatosit secara tegak lurus berdasarkan jarak terdekat (y) dan jarak terjauh (x). Pengukuran menggunakan rumus $\mathrm{x}+\mathrm{y} / 2$. Pengukuran diameter lobulus hepar dilakukan serupa dengan pengukuran diameter hepatosit.

Data yang diperoleh dianalisis menggunakan Analysis of variance (ANOVA) pada taraf signifikansi 5\%, jika terdapat beda nyata maka dilakukan uji lanjut, yaitu dengan uji Duncan dan gambar struktur mikroanatomi hepar puyuh dianalisis dengan metode dskriptif menggunakan fotomikrograf. Parameter yang diamati dalam penelitian ini meliputi diameter hepatosit, diameter lobulus hepar, bobot hepar, bobot badan, dan deskripsi struktur histologi hepar.

\section{HASIL DAN PEMBAHASAN}

Hasil analisis pengaruh pemberian pakan organik terhadap diameter hepatosit, diameter lobulus, bobot hepar, dan bobot badan puyuh jepang dapat dilihat pada Tabel 1. Pengaruh pemberian pakan organik terhadap diameter hepatosit pada puyuh jepang menunjukkan hasil yang berbeda nyata $(\mathrm{P}<0,05)$. Pemberian pakan organik standar (P1) menunjukkan perbedaan nyata dengan pemberian pakan komersial (P0) terhadap diameter hepatosit. Penelitian ini menunjukkan bahwa pemberian pakan organik yang mengandung senyawa fitoestrogen berpengaruh terhadap diameter hepatosit. Kiarie et al., (2014) menjelaskan bahwa pakan organik mengandung bungkil kedelai yang mengandung protein tinggi dan asam amino yang berperan sebagai komponen struktur tubuh yang merupakan bagian dari enzim sebagai prekursor regulasi metabolit dan senyawa fitoestrogen yang terkandung di dalamnya berperan sama dengan estrogen dalam metabolisme di hepar.

Tabel 1. Hasil analisis rataan diameter hepatosit, diameter lobulus, bobot hepar, dan bobot badan setelah pemberian pakan organik pada puyuh jepang (Coturnix coturnix japonica)

\begin{tabular}{lcccc}
\hline \multicolumn{1}{c}{ Parameter } & \multicolumn{1}{c}{$\mathrm{P} 0$} & $\mathrm{P} 1$ & $\mathrm{P} 2$ & $\mathrm{P} 3$ \\
& $\bar{x} \pm \mathrm{sd}$ & $\bar{x} \pm \mathrm{sd}$ & $\bar{x} \pm \mathrm{sd}$ & $\bar{x} \pm \mathrm{sd}$ \\
\hline $\begin{array}{l}\text { Diameter } \\
\text { Hepatosit }(\mu \mathrm{m})\end{array}$ & $21.17^{\mathrm{c}} \pm 0,55$ & $25.32^{\mathrm{b}} \pm 1.58$ & $28.83^{\mathrm{a}} \pm 3.79$ & $29.57^{\mathrm{a}} \pm 1.16$ \\
$\begin{array}{l}\text { Diameter } \\
\text { Lobulus }(\mu \mathrm{m})\end{array}$ & $507.92^{\mathrm{c}} \pm 38.44$ & $572,56^{\mathrm{b}} \pm 27.20$ & $633,84^{\mathrm{a}} \pm 48.63$ & $679,22^{\mathrm{a}} \pm 17.07$ \\
Bobot Hepar $(\mathrm{g})$ & $4.88^{\mathrm{c}} \pm 0.38$ & $5.29^{\mathrm{bc}} \pm 0.47$ & $6.23^{\mathrm{ab}} \pm 0.90$ & $6.50^{\mathrm{a}} \pm 1.00$ \\
Bobot Badan $(\mathrm{g})$ & $192.50^{\mathrm{a}} \pm 15.00$ & $172.50^{\mathrm{a}} \pm 26.30$ & $170.00^{\mathrm{a}} \pm 21.60$ & $180.00^{\mathrm{a}} \pm 14.14$ \\
\hline
\end{tabular}

Keterangan: Angka yang diikuti dengan superskrip yang sama pada baris yang sama menunjukkan tidak berbeda nyata $(\mathrm{P}>0,05)$.

Pemberian pakan organik yang mengandung daun singkong, kunyit, dan ikan kembung (P2) juga meningkatkan diameter hepatosit. Saraswati et al. (2013) menyatakan bahwa banyaknya akumulasi hasil metabolisme yang tersimpan dalam hepatosit ditandai dengan pembentukan 
vakuola pada hepatosit. Marquez et al. (2005) menjelaskan bahwa daun singkong mengandung senyawa $\mathrm{Cu}$-klorofilin, vitamin $\mathrm{A}$, dan provitamin A yang tinggi mampu berperan sebagai antioksidan yang mendukung keberadaan antioksidan endogen dalam hepar.

Kunyit sebagai penyusun pakan organik (P2) dengan kandungan senyawa kurkumin dan fitoestrogen berperan untuk mengoptimalkan efektifitas fungsi hepar. Kasiyati dkk. (2018) menyatakan bahwa kurkumin merupakan komponen bioaktif pada kunyit yang berperan sebagai hepatoprotektor. Efek hepatoprotektor berkaitan dengan aktivitas antioksidan dalam kurkumin sehingga pembentukan radikal bebas dapat ditekan. Rajput et al. (2013) menjelaskan bahwa senyawa kurkumin berperan sebagai antiinflamasi, antikoagulan, dan antibakteri yang berdampak positif terhadap efektivitas fungsi hepar. Saraswati et al. (2014) menjelaskan bahwa senyawa fitoestrogen yang tinggi dalam kunyit mampu mengikat reseptor estrogen yang dapat meningkatkan plasma vitelogenin.

Pemberian pakan organik yang mengandung ikan kembung mampu memperbaiki metabolisme nutrien di dalam hepatosit. Salamah dkk. (2004) menyatakan bahwa ikan kembung mengandung protein sebesar $19,74 \%$. Protein merupakan salah satu sumber dalam pembentukan vitelogenin. Alfiyah dkk. (2015) menyatakan bahwa pembentukan vitelogenin merupakan sintesis lipoprotein yang dikontrol oleh hormon estrogen. Pemberian pakan organik yang mengandung daun singkong, kunyit dan rumput laut (P3) juga mampu meningkatkan diameter hepatosit. Rata-rata diameter hepatosit yang diberi pakan organik P3 sebesar 29,57 $\mu \mathrm{m}$. Horhoruw (2012) menjelaskan bahwa rumput laut kaya akan vitamin $\mathrm{E}$ dan asam lemak esensial yang berupa omega 3 dan omega 6 . Choi et al. (2014) menyatakan bahwa kandungan asam lemak esensial berupa omega 3 dan omega 6 berperan dalam meningkatkan fungsi fisiologis hepar dan menurunkan pembentukan LDL dan VLDL kolesterol dan trigliserida dalam hepar.

Pemberian pakan organik terhadap diameter lobulus hepar pada puyuh jepang menunjukkan hasil yang berbeda nyata $(\mathrm{P}<0,05)$. Hal ini menunjukkan pemberian pakan organik berpengaruh terhadap diameter lobulus hepar.Pemberian pakan organik terhadap diameter lobulus menunjukkan adanya perbedaan secara nyata dibandingkan dengan kontrol. Seiring dengan adanya perbedaan nyata pada diameter hepatosit diikuti dengan perbedaan secara nyata pada diameter lobulus hepar. Woyengo et al. (2011) menjelaskan bahwa lobulus tersusun atas hepatosit yang menyebar secara sentrifugal dari vena sentralis. Peningkatan lobulus hepar dibuktikan dengan peningkatan ukuran diameter sel hepar yang diduga disebabkan oleh adanya peningkatan akumulasi hasil metabolisme.

Pemberian pakan organik terhadap bobot hepar pada puyuh jepang menunjukkan hasil yang berbeda nyata $(\mathrm{P}<0,05)$. Hal ini menunjukkan pemberian pakan organik berpengaruh terhadap bobot hepar. Pemberian pakan organik standar (P1) dibandingkan dengan kontrol (P0) terhadap bobot hepar menunjukkan tidak terdapat perbedaan secara nyata, meskipun pemberian pakan P1 dibandingkan dengan kontrol (P0) menunjukkan terdapat perbedaan nyata terhadap diameter hepatosit dan diameter lobulus. Hal tersebut diduga bahwa bobot hepar dipengaruhi oleh banyaknya lobulus hepar.

Pemberian pakan organik yang mengandung daun singkong, kunyit dan ikan kembung (P2) juga menunjukkan terdapat perbedaan nyata terhadap bobot hepar. Pemberian pakan organik yang mengandung daun singkong, kunyit, dan rumput laut (P3) juga menunjukkan perbedaan nyata dibandingkan kontrol $(\mathrm{P} 0)$ terhadap bobot hepar. Hal ini dikarenakan proses metabolisme nutrien dalam hepar memberikan respons terhadap peningkatan diameter hepatosit dan diameter lobulus hepar. Pemberian pakan P1 dengan P3 menunjukkan perbedaan nyata terhadap diameter hepatosit dan diameter lobulus hepar menyebabkan terdapat perbedaan nyata terhadap bobot hepar. Pemberian pakan organik antara P2 dengan P3 terhadap bobot hepar menunjukkan tidak terdapat perbedaaan nyata. Woyengo et al. (2011) menjelaskan bahwa peningkatan lobulus hepar dan sel penyusun lobulus dikaitkan dengan peningkatan aktivitas metabolisme hepar yang dibuktikan dengan peningkatan ukuran hepar karena nutrisi yang terkandung dalam pakan. 
Pemberian pakan organik terhadap bobot badan puyuh jepang menunjukkan bahwa tidak terdapat perbedaan yang nyata $(\mathrm{P}>0,05)$. Hal ini menunjukkan pemberian pakan organik tidak berpengaruh terhadap bobot badan puyuh. Pemberian pakan organik pada puyuh berpengaruh terhadap diameter hepatosit, diameter lobulus, dan bobot hepar, namun tidak berpengaruh terhadap bobot badan, diduga karena bobot badan tidak hanya dipengaruhi oleh bobot hepar tetapi juga dipengaruhi oleh bobot organ tubuh lainnya dan fase pertumbuhan pada puyuh.
Rata-rata bobot badan pada puyuh jepang yang berumur 5 bulan yaitu berkisar antara 170193 g. Lase dkk. (2008) menyatakan bahwa puyuh betina dewasa memiliki kisaran bobot badan 143$180 \mathrm{~g}$, sehingga bobot badan akhir puyuh jepang dalam penelitian ini sesuai. Bobot badan pada puyuh pada umur 5 bulan dipengaruhi oleh masa pertumbuhan dan masa produktivitas. Suprijatna dkk. (2008) menjelaskan bahwa puyuh jepang yang memasuki umur 5 bulan merupakan fase layer dimana puyuh akan menggunakan energi metabolisme yang dihasilkan oleh organ hepar untuk produktivitas.

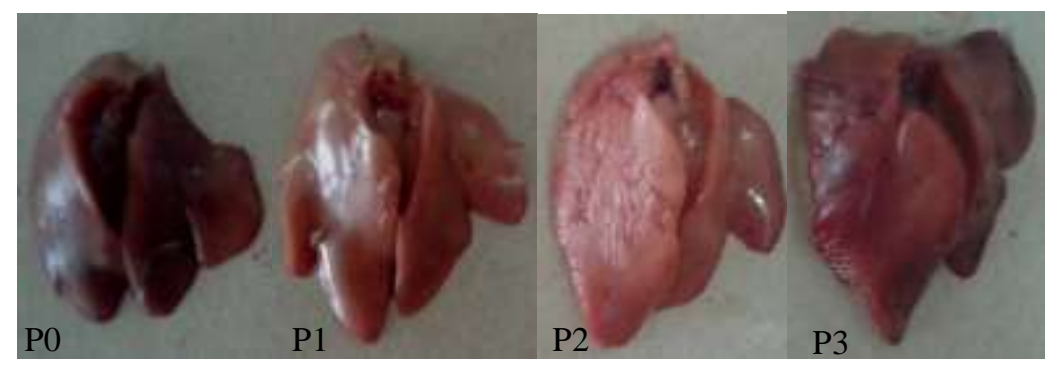

Gambar 1. Warna Hepar Puyuh Jepang (Coturnix coturnix japonica) berumur 5 bulan selama 4 bulan. P0: Pakan komersial; P1: Pakan organik standar; P2: Pakan organik yang mengandung daun singkong, serbuk kunyit dan ikan kembung; P3: Pakan organik yang mengandung daun singkong, serbuk kunyit dan rumput laut.

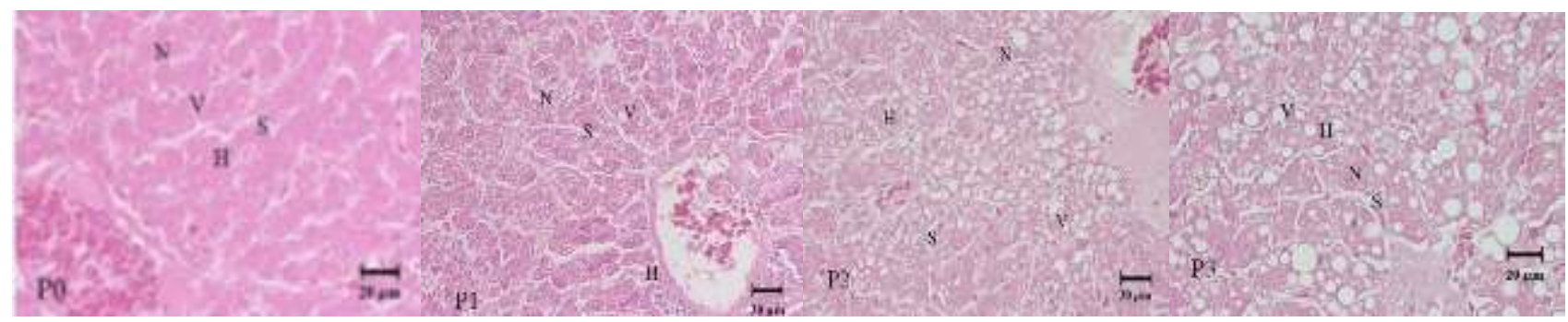

Gambar 2. Penampang melintang Hepatosit Puyuh jepang (Coturnix coturnix japonica). P0: Pakan komersial; P1: Pakan organik standar; P2: Pakan organik yang mengandung daun singkong, serbuk kunyit dan ikan kembung; P3: Pakan organik yang mengandung daun singkong, serbuk kunyit dan rumput laut, (H\&E, 400x). H: Hepatosit, V: Vakuola, N: Nukleus, S: Sinusoid.

Hasil pengamatan secara kualitatif terhadap warna hepar puyuh jepang (Coturnix coturnix japonica) secara makroskopis pada umur 5 bulan setelah diberi perlakuan kontrol (P0) menghasilkan warna hepar yang lebih gelap jika dibandingkan dengan warna hepar yang diberi pakan organik P1, P2 dan P3. Pemberian pakan organik P1, P2, dan P3 menunjukkan warna lebih terang pada hepar dibandingkan dengan kontrol. Hal ini diduga bahwa penggunaan pakan organik menunjukkan adanya akumulasi vitelogenin dalam hepatosit yang lebih banyak. Hal ini sesuai dengan hasil penelitian Saraswati (2013) menyatakan bahwa hepar puyuh jepang yang masih aktif mensintesis prekursor kuning telur terlihat berwarna merah kekuningan, sedangkan yang tidak aktif mensintesis prekursor kuning telur terlihat berwarna merah tua. Bilgili (2002) melaporkan bahwa warna hepar yang lebih terang pada unggas yang diberi pakan dikaitkan dengan konsentrasi akumulasi vitelogenin dalam hepatosit yang lebih tinggi dan lebih banyak vakuola yang tersebar, 
sedangkan hepar berwarna lebih gelap pada unggas memiliki konsentrasi vitelogenin yang lebih rendah.

Hasil pengamatan secara kualitatif terhadap struktur histologi hepar puyuh jepang (Coturnix coturnix japonica) secara mikroskopis setelah diberi perlakuan pakan organik dapat dilihat berdasarkan susunan hepatosit dan banyaknya vakuola. Hepatosit pada perlakuan P0 dan P1 tersusun secara radier ke arah vena sentral, sedangkan pada perlakuan P2 dan P3 susunan hepatosit tidak teratur. Vakuola yang menunjukkan adanya akumulasi vitelogenin pada perlakuan P2 dan P3 terlihat lebih banyak dibandingkan dengan P0 dan P1. Penambahan gizi seperti serat, asam lemak esensial dan senyawa kurkumin dapat mengoptimalkan fungsi hepar. Suprijatna dkk. (2008) menjelaskan bahwa pakan organik dalam ransum berperan dalam mengoptimalkan kerja sel hepar sebagai tempat metabolisme nutrien dan sintesis vitelogenin.

\section{KESIMPULAN}

Berdasarkan hasil penelitian, pemberian pakan organik mampu meningkatkan diameter hepatosit, diameter lobulus hepar, dan bobot hepar, maka dapat disimpulkan bahwa pemberian pakan organik mampu mengoptimalkan fungsi hepar puyuh umur 5 bulan.

\section{DAFTAR PUSTAKA}

Alfiyah, Y., K. Praseno dan S. M. Mardiati. 2015. Indeks Kuning Telur (IKT) dan Haugh Unit (HU) Telur Itik Lokal dari Beberapa Tempat Budidaya Itik di Jawa. Buletin Anatomi dan Fisiologi 23 (2):7-14.

Bahri, S dan Rusdi. 2008. Evaluasi Energi Metabolis Pakan Lokal pada Ayam Petelur. Jurnal Agroland 15 (1):75-78.

Bilgili, S. F. 2002. Slaughter Quality as Influenced by Feed Withdrawal. Worlds Poult. Sci. J 58:123-130.

Choi, Y.J., S. R. Lee and J. W. Oh. 2014. Effects of Dietary Fermentedd Seaweed and Seaweed Fusiforme on Growth Performance, Carcass Parameters and
Immunoglobulin Concentration in Broiler Chicks. Asian Australas. J. Anim. Sci 27(6):862-870.

Direktorat Jenderal Peternakan dan Kesehatan Hewan. 2015. Populasi dan Produksi Peternakan di Indonesia. Kementerian Pertanian, Jakarta.

Horhoruw, W.M. 2012. Ukuran Saluran Reproduksi Ayam Petelur Fase Pullet yang diberi Pakan dengan Campuran Rumput Laut (Gracilaria edulis). J. Agrinimal 2(2):75-80.

Kasiyati, Sumiati, D. R. Ekastuti dan W. Manalu. 2018. Pemanfaatan Kurkumin dan Cahaya Monokromatik dalam Meningkatkan Performa Produksi dan Mutu Telur Itik Lokal. J.Agronomika 12(2):159-165.

Kiarie, E., L. F. Romero and V. Ravindran. 2014. Growth Performance, Nutrient Utilization, and Digesta Characteristic in Broiler Chickens Fed Corn or Wheat Diets without or with Suplemental Xylanase. Journal of Poultry Science 93 (1):1186-1196.

Lase, H.G., E. Sujana dan H. Indrijani. 2008. Performa pertumbuhan puyuh (Coturnix coturnix japonica) Petelur Betina Silangan Warna Bulu Coklat dan Hitam di Pusat Pembibitan Puyuh Universitas Padjadjaran. E-Journal Unpad 25 (2):1-7.

Marquez, U. M. L., R. M. C. Barros and P. Sinnecker. 2005.Antioxidant Activity of Chlorophylls and Their Derivates. Food Research International38:885-891.

Rajput, N., N. Muhammad,R. Yan, X. Zhong and T. Wang. 2013. Effect of Dietary Supplementation of Curcumin on Growth Performance, Intestinal Morphology and Nutrients Utilization of Broiler Chicks. Japan Poultry Science Association50 (1):44-52.

Salamah, E., Hendrawan, dan Yunizal. 2004. Studi tentang Asam lemak Omega-3 dari Bagian-bagian Tubuh Ikan Kembung Jantan (Rastrelliger kanagurta). Buletin Teknologi Hasil Perikanan 8 (2):30-36. 
Saraswati, T. R., W. Manalu,D. R. Ekastuti and N. Kusumorini. 2013. Increased Egg Production of Japanese Quail (Coturnix japonica) by Improving Liver Function Through Tumeric Powder Supplementation. International Journal of Poultry Science 12 (10):601-614.Saraswati, T. R.2014. Effect of Tumeric Powder to Estriol and Progesterone Hormone Profil of Laying Hens During One Cycle of Ovulation. In. J. of Poultry Science 13(9):504-509.

Suprijatna, E., S. Kismiati dan N. R. Furi. 2008. Penampilan Produksi dan Kualitas Telur pada Puyuh yang Memperoleh Protein Rendah dan Disuplementasi Enzim Komersial. J. Indon. Trop. Anim. Agric. Fakultas Peternakan Universitas Dipenogoro, Semarang.

Widyastuti, W., S. M. Mardiati dan T. R. Saraswati. 2014. Pertumbuhan Puyuh (Coturnix coturnix japonica) setelah Pemberian Tepung Kunyit (Curcuma longa L.) pada Pakan. Buletin Anatomi dan Fisiologi 22 (2):12-20.

Woyengo, T.A., E. Kiarie and C. M. Nyachoti. 2011. Growth Performance, Organ Weights, and Blood Parameters of Broilers Fed Diets Containing Expeller-Extacted Canola Meal. J. Poultry Science 90: 25202527.

Zahra, A.A., D. Sunarti dan E. Suprijatna. 2012. Pengaruh Pemberian Pakan Bebas Pilih (Free Choice Feeding) terhadap Performan Produksi Telur Burung Puyuh (Coturnix coturnix japonica). Animal Agricultural Journal 1 (1):1-11. 